\title{
Soil biochar amendment in a nature restoration area: effects on plant productivity and community composition
}

\author{
Tess F. J. van de Voorde, ${ }^{1}$ T. Martijn Bezemer, ${ }^{2}$ Jan Willem Van Groenigen, ${ }^{3}$ Simon Jeffery, ${ }^{3}$ \\ AND LiesJe Mommer ${ }^{1,4}$ \\ ${ }^{1}$ Nature Conservation and Plant Ecology Group, Wageningen University, P.O. Box 47, 6700 AA Wageningen, The Netherlands \\ ${ }^{2}$ Department of Terrestrial Ecology, Netherlands Institute of Ecology (NIOO-KNAW), P.O. Box 50, 6700 AB Wageningen, \\ The Netherlands \\ ${ }^{3}$ Department of Soil Quality, Wageningen University, P.O. Box 47, 6700 AA Wageningen, The Netherlands \\ ${ }^{4}$ Experimental Plant Ecology, Radboud University Nijmegen, P.O. Box 9100, 6500 GL Nijmegen, The Netherlands
}

Abstract. Biochar (pyrolyzed biomass) amendment to soils has been shown to have a multitude of positive effects, e.g., on crop yield, soil quality, nutrient cycling, and carbon sequestration. So far the majority of studies have focused on agricultural systems, typically with relatively low species diversity and annual cropping schemes. How biochar amendment affects plant communities in more complex and diverse ecosystems that can evolve over time is largely unknown. We investigated such effects in a field experiment at a Dutch nature restoration area.

In April 2011, we set up an experiment using biochar produced from cuttings collected from a local natural grassland. The material was pyrolyzed at $400^{\circ} \mathrm{C}$ or at $600^{\circ} \mathrm{C}$. After biochar or residue (non-pyrolyzed cuttings) application (10 Mg/ha), all plots, including control $(0 \mathrm{Mg} /$ ha) plots, were sown with an 18-species grassland mixture. In August 2011, we determined characteristics of the developed plant community, as well as soil nutrient status.

Biochar amendment did not alter total plant productivity, but it had a strong and significant effect on plant community composition. Legumes were three times as abundant and individual legume plants increased four times in biomass in plots that received biochar as compared to the control treatment. Biomass of the most abundant forb (Plantago lanceolata) was not affected by biochar addition. Available phosphorous, potassium, and $\mathrm{pH}$ were significantly higher in soils that received biochar than in Control soils. The rate of biological nitrogen fixation and seed germination were not altered by biochar amendment, but the total amount of biological $\mathrm{N}$ fixed per Trifolium pratense (red clover) plant was more than four times greater in biochar-amended soil.

This study demonstrates that biochar amendment has a strong and rapid effect on plant communities and soil nutrients. Over time these changes may cascade up to other trophic groups, including above- and belowground organisms. Our results emphasize the need for long-term studies that examine not only the short-term effects of biochar amendment, but also follow how these effects evolve over time and affect ecosystem functioning.

Key words: biochar; biological nitrogen fixation; black carbon; carbon sequestration; charcoal; climate change mitigation; compensatory dynamics; ecosystem functioning; nature restoration; plant nutrients; soil nutrients.

\section{INTRODUCTION}

Soil amendment with biochar, which is pyrolyzed biomass (Lehmann and Joseph 2009), is advocated as a means to sequester carbon (C) in the soil and improve soil fertility (Lehmann et al. 2006, Sohi et al. 2010, Woolf et al. 2010). Biochar amendment to soils has been reported to increase yields in various cropping systems (e.g., Glaser et al. 2002, Jeffery et al. 2011, Kammann et al. 2011, Vaccari et al. 2011, Spokas et al. 2012, Wang et al. 2012). Also, several studies have claimed beneficial

Manuscript received 26 March 2013; revised 19 September 2013; accepted 29 October 2013. Corresponding Editor: R. L. Sinsabaugh.

${ }^{5}$ E-mail: tess.vandevoorde@wur.nl effects of biochar with regard to reduction of nutrient leaching and greenhouse gas emissions (e.g., Singh et al. 2010, Liu et al. 2011). While biochar has been shown to be able to affect a variety of ecosystem services, the effects are not always in the same direction nor of similar magnitude (Jeffery et al. 2011).

Most studies examining biochar effects on plants have used individual plants or have been performed in monocultures in agricultural settings (as reviewed in Jeffery et al. [2011]), which generally are nutrient-rich, low in diversity, and have short, yearly cropping cycles. Investigations with other sources of recalcitrant carbon amended to soils, such as charcoal amended to tropical soils (Glaser et al. 2002, Major et al. 2005), Amazonian terra preta soils (Sombroek 1966), or the remains of 
natural fires in (boreal) forests (Mikan and Abrams 1996), suggest that recalcitrant carbon sources can affect plant performance, plant competition, and ecosystem functioning. So far, studies that examine the effects of biochar on multiple plant species interactions and thus on plant community composition are scarce, particularly in natural ecosystems. Plant communities in natural grasslands and in grassland restoration areas are typically characterized by a higher diversity, and consist of a larger proportion of perennial species, than agricultural systems. Grassland systems are therefore very suitable to study the consequences of soil biochar amendment on plant-plant interactions and consequent shifts in community composition. Moreover, biochar application in nature restoration areas on former arable fields has been suggested to immobilize the available nitrogen, and is therefore thought to be a potential way to reduce soil fertility of nutrient-rich, abandoned agricultural fields, which is a prerequisite to restore nature in these areas (Perry et al. 2010). The effect of biochar on soil fertility seems contradictory: $\mathrm{N}$ in the biochar may increase the nutrient status, but the very high $\mathrm{C}$ content may immobilize N. Following this last reasoning, several field studies have indeed shown that hay or straw addition to the soil can increase microbial nitrogen immobilization, and consequently decrease soil $\mathrm{N}$ availability (Blumenthal et al. 2003, Kardol et al. 2009, Perry et al. 2010). Other studies have shown that addition of activated carbon to restored grasslands can reduce the establishment of exotic weeds in these fields by affecting soil biota or by absorbing allelochemicals (Callaway 2000, Kulmatiski 2011). Biochar addition may also affect such soil conditions, depending on its availability, although the effects of activated carbon may not be directly translated to potential effects of biochar, as activated carbon often has a higher absorbing capacity and contains less nutrients (Angin et al. 2013).

Results from a recent meta-analysis showed that biochar amendment to agricultural soils increased overall crop yield by $\sim 10 \%$ (Jeffery et al. 2011). Interestingly, the stimulating effect of biochar differed between crop species. Productivity of radishes and soy bean was increased, for example, but that of rye grass diminished when biochar was added to the soil (Jeffery et al. 2011). These results suggest that biochar addition to soil may affect plant-plant interactions and may alter plant community composition, as was also shown for other charcoal sources (e.g., Major et al. 2005). Similar results were found in an agricultural field trial with maize and grass over three years, where the effects of biochar amendment were also found to be crop dependent (Jones et al. 2012), and in a forest system, where the growth of two Quercus species was differentially affected by charcoal addition (Mikan and Abrams 1996). These observations suggest that in natural systems, where plant communities are highly diverse, biochar amendment may alter the productivity, but also the competitive hierarchy of plant species, which, over time, may lead to alterations in plant community composition.

Biochar amendment can change plant community composition via two different mechanisms: (1) by affecting seed germination rates and plant establishment, and (2) by affecting the growth of particular plant species or functional groups of plants. Studies that examined how biochar amendment affects seed germination have yielded inconsistent data so far. Some studies report that biochar does not affect germination (i.e., Free et al. 2010, Jones et al. 2012), whereas others find increased germination, even at relatively low application rates (e.g., Van Zwieten et al. 2010). Solaiman et al. (2011) observed species-dependent effects (positive and negative) of biochar on the germination of wheat, mung bean, and subterranean clover. Effects of biochar on the growth of particular plant species or groups of plants can be explained by biochar-mediated changes in soil variables, such as increased soil $\mathrm{pH}$ (e.g., Van Zwieten et al. 2010, Jeffery et al. 2011, Jones et al. 2012), increased soil macro- and micronutrient availability (e.g., Lehmann et al. 2003, Rondon et al. 2007, Jones et al. 2012), or altered soil water holding capacity (Downie et al. 2007). All these conditions are known to potentially affect the competitive outcome between plant species and thus plant community composition. Legumes in particular have been found to respond strongly to the addition of biochar to soils (Jeffery et al. 2011).

In this study, we examined the effect of soil amendment with biochar on plant productivity and community composition in a species-rich restoration grassland. We specifically focused on the effects of biochar addition on germination, and, via altered soil nutrient status, on the competitive performance of different plant species. To test this, we set up a field experiment in a nature restoration area in the Netherlands in 2011. The experiment consisted of four treatments, two biochar treatments (biochar produced from the same feedstock at $400^{\circ} \mathrm{C}$ or at $600^{\circ} \mathrm{C}$ ), and two control treatments, one in which we incorporated the non-pyrolyzed biomass (i.e., hay residue), and a treatment to which no substrate was added. We examined the effects of two biochars originating from the same feedstock but produced at two temperatures, to test how the type of biochar would affect plant and soil parameters. Biochars produced at higher temperatures are predicted to be more recalcitrant and have higher $\mathrm{C}$ content (Gundale and DeLuca 2006, Spokas 2010, Zimmerman 2010).We hypothesized that biochar amendment increases total plant productivity and alters community composition as compared to the addition of non-pyrolyzed biomass or no soil amendment.

\section{Material and Methods}

Experimental field site

To study the effects of biochar amendment on plant community characteristics and soil nutrients, a field 
experiment was set up in a nature restoration area near Ede, The Netherlands $\left(52^{\circ} 04^{\prime} \mathrm{N}, 05^{\circ} 45^{\prime} \mathrm{E}\right)$. This area of 180 ha is of glacial origin (Saalien ice age) and is on a sandy soil (93.9\% sand, $5.3 \%$ silt, $3.4 \%$ clay). The soil is characterized as a "holtpodzol" on coarse sand (gY30VIII; Stiboka 1975: map 40W), with a soil organic C content of $2.8 \%$. In this area, agriculture was abandoned in 1996, and the field has been extensively grazed with cattle since then. The experimental field site is fenced off.

\section{Biochar production and characteristics}

In October 2010, 1 ha of the area was mowed and the collected aboveground biomass was dried and used for biochar production. First, the biomass was cut into pieces of $2-3 \mathrm{~cm}$. Part of the cuttings were pyrolyzed for five minutes at $400^{\circ} \mathrm{C}$ or at $600^{\circ} \mathrm{C}$ at Biogreen, ETIA, France, using a Biogreen 130 pyrolyzer with a continuous flow of $10 \mathrm{~kg} / \mathrm{h}$. The remaining part of the cuttings were not pyrolyzed, and were used as a non-pyrolyzed soil amendment (hay residue). As the seed stock in the biochar cuttings was killed during pyrolysis, the hay residue was sterilized by gamma irradiation $(>25 \mathrm{kGy}$ [kilograys] of gamma irradiation [Isotron, Ede, The Netherlands]) in order to kill the seed stock.

Nutrient content $\left(\mathrm{N}, \mathrm{PO}_{4}\right.$, and $\left.\mathrm{K}\right)$ and $\mathrm{pH}-\mathrm{H}_{2} \mathrm{O}$ in the biochars and hay residue were analyzed $(n=3)$ following similar protocols as described for soil material.

\section{Experimental field design}

The field experiment started in April 2011 and consisted of 4 treatments and 6 replicate blocks, resulting in 24 plots in total, set up as a randomized complete block design. The four treatments are: incorporation of biochar produced at $400^{\circ} \mathrm{C}$ (Biochar 400 ), biochar produced at $600^{\circ} \mathrm{C}$ (Biochar 600), incorporation of the non-pyrolyzed cuttings from which the biochar was produced (Hay residue), and a control treatment in which no material was incorporated (Control). Each plot measured $4 \times 4 \mathrm{~m}$, and plots were separated by $1 \mathrm{~m}$ wide paths. Biochar and residue were only incorporated within the inner $3 \times 3 \mathrm{~m}$ of each $4 \times 4$ $\mathrm{m}$ plot to further increase the buffer zone between plots. All measurements were conducted within the inner $3 \times 3$ $\mathrm{m}$ area of each plot.

Biochar and hay residue were applied at a rate of 1.3 $\mathrm{kg} / \mathrm{m}^{2}$, which corresponds to an application rate of $1 \%$ $(\mathrm{m} / \mathrm{m})$ or $10 \mathrm{Mg} /$ ha. After applying the amendments to the surface, the top $10-15 \mathrm{~cm}$ of the soil was mixed using a rotavator. control plots were also rotavated. All plots were then sown with an 18-species seed mixture: 7 forbs (Achillea millefolium, Crepis capillaris, Hypericum perforatum, Hypochaeris radicata, Leucanthemum vulgare, Linaria vulgaris, Plantago lanceolata), 7 grass species (Agrostis capillaris, Anthoxanthum odoratum, Dactylis glomerata, Festuca rubra, Holcus lanatus, Phleum pratense, Poa pratensis), and 4 legume species (Lotus corniculatus, Trifolium pratense, Trifolium repens, Vicia cracca). Seeding density was $\sim 5000$ seeds $/ \mathrm{m}^{2}$, and species were mixed in an equal ratio based on seed mass. Seeds were ordered from an commercial organic seed supplier (De Bolderik, Wervershoof, The Netherlands). In October 2011 the field was mown and all aboveground biomass was removed from the field. Paths between the plots were mown once per month during the growing season.

\section{Soil nutrients}

The effects of the soil amendments on soil nutrients were measured twice: directly after the treatments were initiated (April 2011), and at the end of the first growing season (August 2011). Each time, six soil cores $(3 \mathrm{~cm}$ diameter and $10 \mathrm{~cm}$ depth) were taken per plot to determine soil nutrients. Three cores were combined, resulting in two mixed soil samples per plot. These samples were dried at $40^{\circ} \mathrm{C}$ for three days. Available N$\mathrm{NO}_{3}, \mathrm{~N}-\mathrm{NH}_{4}$, and $\mathrm{P}_{-} \mathrm{PO}_{4}$ were determined photometrically $(540 \mathrm{~nm})$ in a $1: 10(\mathrm{~m} / \mathrm{v}) 0.01 \mathrm{~mol} / \mathrm{L} \mathrm{CaCl}_{2}$ extract (Houba et al. 1986, 2000, Kulhánek et al. 2009) using an auto-analyzer (Skalar Analytical, Breda, The Netherlands). $\mathrm{K}$ was measured in the same extract on an atomic absorption spectrometer (AA240FS; Varian, Palo Alto, California, USA). Micronutrient contents of Al, As, B, $\mathrm{Ba}, \mathrm{Cd}, \mathrm{Co}, \mathrm{Cr}, \mathrm{Cu}, \mathrm{Fe}, \mathrm{Hg}, \mathrm{Li}, \mathrm{Mg}, \mathrm{Mn}, \mathrm{Mo}, \mathrm{Ni}, \mathrm{Pb}$, $\mathrm{Se}, \mathrm{Sn}, \mathrm{Sr}, \mathrm{Zn}$ were measured in the same $\mathrm{CaCl}_{2}$ extracts, using an ICP-MS (Element 2, Thermo X series; Thermo Fisher Scientific, Waltham, Massachusetts, USA). Soil $\mathrm{pH}$ was measured in a $1: 5(\mathrm{~m} / \mathrm{v}) 1 \mathrm{~mol} / \mathrm{L} \mathrm{KCl}$ solution using a WTW pH 522 probe (WTW, Weilheim, Germany). Moisture content of the fresh field soil was determined gravimetrically $\left(105^{\circ} \mathrm{C}, 48\right.$ hours $)$ and organic matter content was determined by loss on ignition $\left(550^{\circ} \mathrm{C}\right.$, three hours).

\section{Plant community composition, production and nutrient content}

In August 2011, at peak standing biomass, the estimated percentage cover of each species was recorded on a continuous scale by visual estimations in four $1 \times 1$ $\mathrm{m}$ quadrats per plot. In October, total aboveground plant biomass was clipped at soil level in two $0.5 \times 1 \mathrm{~m}$ plots per plot. The biomass was dried at $70^{\circ} \mathrm{C}$ for five days, and weighed. For the two most abundant species (Plantago lanceolata and Trifolium pratense), we clipped the aboveground biomass of five randomly selected individuals per plot. The plants were oven-dried $\left(40^{\circ} \mathrm{C}\right.$ for three days) and weighed. For three randomly selected plants of both species, total N, P, and $\mathrm{K}$ concentrations were measured using the oven-dried biomass. These nutrients were also measured in three randomly selected Holcus lanatus and Vicia cracca individuals per plot. Dried plants were ground (to $\sim 1$ $\mathrm{mm}$ ), homogenized per species per plot, and decomposed using $\mathrm{H}_{2} \mathrm{SO}_{4}$-Se and salicylic acid (Novozamsky et al. 1983). Nutrients were subsequently analyzed as described for the soil samples (see Soil nutrients). 


\section{Biological nitrogen fixation}

Biological $\mathrm{N}$ fixation (BNF) rates in the field by the legumes $T$. pratense and $V$. cracca were determined using the natural abundance method, which is based on the natural ${ }^{15} \mathrm{~N}$ enrichment of plant-available soil $\mathrm{N}$ relative to atmospheric $\mathrm{N}_{2}$ (Shearer and Kohl 1986). As non-N fixing reference species, three Leucanthemum vulgare and $P$. lanceolata plants were selected in each plot. All plants were dried $\left(40^{\circ} \mathrm{C}\right.$, three days) and chopped to $\sim 1 \mathrm{~mm}$ size. The three individuals per species per plot were homogenized, and a subsample of the mixture was ball milled. Total $\mathrm{C}$ and $\mathrm{N}$ content, and the $\delta^{15} \mathrm{~N}$ signature of the plants were determined using a PDZ Europa ANCA-GSL elemental analyzer interfaced to a PDZ Europa 20-20 isotope ratio mass spectrometer (Sercon Limited, Cheshire, UK) at the UC Davis Stable Isotope Facility, Davis, California, USA. The percentage of plant-derived $\mathrm{N}$ from atmospheric $\mathrm{N}_{2}$ (\% $\mathrm{Ndfa}$ ) was calculated according to Shearer and Kohl (1986): $\% \mathrm{Ndfa}=100 \times\left(\left(\delta^{15} \mathrm{Nref}-\delta^{15} \mathrm{Nleg}\right) /\left(\delta^{15} \mathrm{Nref}-c\right)\right)$, where $\delta^{15} \mathrm{Nref}$ is the average $\delta^{15} \mathrm{~N}$ of the non-fixing reference plants, $\delta^{15} \mathrm{Nleg}$ is $\delta^{15} \mathrm{~N}$ of the legume, and $c$ is a standard value, the $\delta^{15} \mathrm{~N}$ value of legumes without BNF. As a value for the constant $c$ we used the minimal $\delta^{15} \mathrm{~N}$ value we observed for each of the investigated species. Total Ndfa per $T$. pratense plant per treatment was calculated as: $\% \mathrm{Ndfa} \times$ plant $\mathrm{N}$ content $\times$ plant dry mass.

\section{Germination}

The effect of soil amendment with biochar on the germination rate of each of the 18 sown species was tested in a laboratory experiment in petri dishes with soil with or without addition of $1 \%(\mathrm{~m} / \mathrm{m})$ biochar 600 . Each petri dish contained $50 \mathrm{~g}$ of field soil (17\% moisture content). Sixteen surface-sterilized (1 minute in $1 \%$ bleach solution) seeds per species were placed on top of the soil in a $4 \times 4$ grid. Each treatment was replicated five times per species, resulting in $2 \times 5 \times 18=180$ petri dishes. Petri dishes were stored at room temperature, brought back to their initial mass twice a week, and germination was checked every two or three days. The experiment was finished when no new seeds had germinated for one week. Total percentage germination was determined after 36 days.

\section{Data analyses}

Data were analyzed using univariate (Genstat 14; Payne et al. 2008) or multivariate statistics (Canoco 4.55; Ter Braak and Šmilauer 2002). For all statistical analyses, data from multiple samples taken within one field plot were averaged before analyses, as they are pseudoreplicates. This resulted in 24 data points for all analyses of data collected from the field experiment (four treatments $\times$ six replicate blocks).

Univariate analyses.-All treatment effects (Biochar 400 , Biochar 600 [the number refers to the temperature used during pyrolysis], Hay residue, and Control treatment) were analyzed using analysis of variance (ANOVA). When analyses included different plant species, a two-way ANOVA with species identity and treatment as main factors, including their interaction, was conducted. All analyses of data of the field experiment included block identity as random factor. Individual comparisons were based on a Tukey's HSD post hoc test. Before conducting ANOVA, data were checked for homogeneity of variances using Cochran's, Hartley's, and Bartlett tests $(P<0.01)$ and for normality by inspection of the normal-probability plot. The percentage germination in petri dishes was compared using two-way ANOVA with species identity and biochar addition (with/without) as main factors. All ANOVA tests included the interaction between factors, but only significant interactions are described in the text. To fulfill requirements of normality, soil nutrients and biomass were log-transformed, percentage data were arcsine-transformed, and total percentage cover and germination were square root-transformed prior to statistical analyses.

Multivariate analyses.-The composition of the plant communities in the different treatments was analyzed using multivariate statistics. Detrended correspondence analysis (DCA) indicated that linear analyses were most appropriate; the longest gradient was $<3$ (Lepš et al. 2003). Community composition was described using principal components analysis (PCA) and treatment effects on community composition were tested using redundancy analysis (RDA). Significant differences between treatments were inferred by Monte Carlo permutation tests (999 permutations). Plant community cover data was log-transformed prior to analyses. Species that were recorded on less than three occasions were excluded from these analyses.

\section{RESUlts}

\section{Characteristics of soil amendments}

Total $\mathrm{C}$ and $\mathrm{N}$ content of the biochar produced at $600^{\circ} \mathrm{C}$ were significantly higher than that of the biochar produced at $400^{\circ} \mathrm{C}$ and the hay residue (Table 1). Both biochar types had a $\mathrm{pH}$ that was significantly higher than that of the hay residue (Table 1). Extractable $\mathrm{PO}_{4}$ was three times higher in the biochar produced at $400^{\circ} \mathrm{C}$ than in biochar produced at $600^{\circ} \mathrm{C}$. Potassium levels in both biochars were high, but did not differ between the two types (Table 1).

\section{Soil nutrients}

At the start of the field experiment, directly following soil amendment, there were no significant differences between treatments with respect to soil nutrients or $\mathrm{pH}$ (Table 2). However, at the end of the first growing season, available $\mathrm{K}$ was two times higher and $\mathrm{pH} 0.3$ units higher in both biochar treatments than in the Control; Hay residue had intermediate values $\left(\mathrm{K}, F_{3,15}=\right.$ 9.40, $P<0.001 ; \mathrm{pH}, F_{3,15}=6.82, P=0.004$; Table 2). Extractable $\mathrm{PO}_{4}$ was significantly higher in the Biochar 
TABLE 1. Average percentage, before soil application, of total $\mathrm{C}$ and $\mathrm{N}$ in the biochar produced at $400^{\circ} \mathrm{C}(\mathrm{Biochar} 400)$, or at $600^{\circ} \mathrm{C}$ (Biochar 600) and in the hay residue; and average mineral $\mathrm{N}, \mathrm{PO}_{4}$, and $\mathrm{K}$ content of both biochars.

\begin{tabular}{lccccc}
\hline \multicolumn{1}{c}{ Parameters } & Biochar 400 & Biochar 600 & Hay residue & $F$ or $t$ & $P$ \\
\hline Total C $(\%)$ & $41.8 \pm 0.3 \mathrm{a}$ & $57.7 \pm 1.7 \mathrm{~b}$ & $41.7 \pm 0.3 \mathrm{a}$ & $F_{2,6}=78.4$ & $<\mathbf{0 . 0 0 1}$ \\
Total N (\%) & $1.67 \pm 0.05 \mathrm{a}$ & $2.05 \pm 0.03 \mathrm{~b}$ & $1.49 \pm 0.06 \mathrm{a}$ & $F_{2,6}=37.3$ & $<\mathbf{0 . 0 0 1}$ \\
$\mathrm{C}: \mathrm{N}$ & $25.2 \pm 0.6$ & $28.2 \pm 1.2$ & $28.1 \pm 1.0$ & $F_{2,6}=3.39$ & 0.10 \\
$\mathrm{pH} \mathrm{H} \mathrm{H}_{2} \mathrm{O}$ & $8.5 \pm 0.03 \mathrm{~b}$ & $9.82 \pm 0.03 \mathrm{c}$ & $6.09 \pm 0.01 \mathrm{a}$ & $F_{2,6}=5283$ & $<\mathbf{0 . 0 0 1}$ \\
$\mathrm{Mineral} \mathrm{N}(\mathrm{mg} / \mathrm{kg})_{\mathrm{P}-\mathrm{PO}}(\mathrm{mg} / \mathrm{kg})$ & $0.8 \pm 0.03$ & $0.8 \pm 0.06$ & & $t_{1,4}=1.30$ & 0.26 \\
$\mathrm{~K}(\mathrm{mg} / \mathrm{kg})$ & $1.9 \pm 0.02 \mathrm{~b}$ & $0.6 \pm 0.03 \mathrm{a}$ & & $t_{1,4}=22.0$ & $<\mathbf{0 . 0 0 1}$ \\
\hline
\end{tabular}

Notes: Means $( \pm \mathrm{SE})$ and $P$ values of ANOVA or two-sided $t$ test testing differences between treatments are presented. Within rows, entries followed by the same letter are not significantly different $(P<0.05)$ based on a Tukey's HSD test $(n=3)$. Values in boldface are significant.

400 treatment than in the Control treatment $\left(F_{3,15}=5.22\right.$, $P=0.01$; Table 2). The micronutrients $\mathrm{Cd}$ and $\mathrm{Zn}$ were significantly lower in the Biochar 600 treatment than in the Hay residue or Control treatment, respectively; and $\mathrm{Pb}$ was significantly higher in the Biochar 600 treatment than in the Control treatment (data not shown).

\section{Plant community composition and production}

In August, a total of 39 plant species were recorded in the experimental plots, among which were 17 of the 18 species that were sown; only $H$. perforatum did not establish (Appendix: Table A1). Twenty-one non-sown species, mainly early-successional agricultural weeds, also established in the plots. The species $P$. lanceolata and $T$. pratense were the two most abundant species and made up $>65 \%$ of the total plant cover (Appendix: Table A1).

Plant community composition differed significantly between treatments after the first growing season (RDA, $F=2.68, P=0.02,34.9 \%$ ), but the composition did not differ between the two different biochar treatments (Fig. 1). The PCA analysis (Fig. 1) showed that the legume $T$. pratense was most characteristic for the biochar plots (34\% abundance; Appendix: Table A1). The most characteristic species in the Control plots was the grass
D. glomerata, whereas the hay residue plots were characterized by bare soil $(6 \%$; Table 3$)$. The same pattern was observed when the abundance of plant functional groups was compared. Legume cover was significantly higher in the biochar plots than in the Control plots (Table 3 ). In the hay residue plots grasses were less abundant and non-sown species more abundant than in the control plots (Table 3 ).

Total biomass production per square meter did not differ between the treatments $\left(F_{3,15}=0.95, P=0.44\right.$; Fig. 2a). However, biomass of individual $T$. pratense plants was four times higher in both biochar treatments than in the Control and two times higher than in the Hay residue treatment $\left(F_{3,15}=13.01, P<0.001\right.$; Fig. $\left.2 b\right)$. Biomass of $P$. lanceolata did not differ significantly between treatments $\left(F_{3,15}=1.28, P=0.32\right.$; Fig. 2 c) .

\section{Germination}

Germination rates of the 18 species sown in the field experiment differed significantly between species $\left(F_{17,144}\right.$ $=47.3, P<0.001)$, but were not altered by biochar addition $\left(F_{1,144}=0.19, P=0.66\right)$ (Appendix: Table A2). There was no significant relationship between germination percentage and the abundance of a species in the

TABLE 2. Overview of the average soil nutrient content and soil characteristics of the four experimental treatments at the start of the experiment (April 2011) and at harvest (August 2011). Means ( \pm SE) and $F$ and $P$ values of ANOVA testing differences between treatments are presented.

\begin{tabular}{|c|c|c|c|c|c|c|c|}
\hline Date & Parameters & Biochar 400 & Biochar 600 & Hay residue & Control & $F_{3,15}$ & $P$ \\
\hline April 2011 & 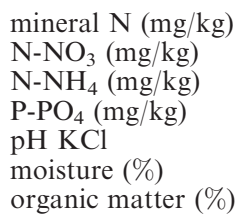 & $\begin{array}{c}8.7 \pm 1.4 \\
5.6 \pm 0.3 \\
3.1 \pm 1.6 \\
4.4 \pm 0.2 \\
5.07 \pm 0.06 \\
11.3 \pm 0.2 \\
4.18 \pm 0.13\end{array}$ & $\begin{aligned} & 8.0 \pm 2.00 \\
& 5.0 \pm 1.76 \\
& 3.0 \pm 0.95 \\
& 4.2 \pm 0.18 \\
& 4.92 \pm 0.06 \\
& 11.2 \pm 0.4 \\
& 4.24 \pm 0.15\end{aligned}$ & $\begin{array}{c}9.6 \pm 2.8 \\
5.5 \pm 0.9 \\
4.1 \pm 2.1 \\
4.1 \pm 0.3 \\
4.99 \pm 0.09 \\
11.7 \pm 0.6 \\
4.22 \pm 0.19\end{array}$ & $\begin{array}{l}6.9 \pm 1.2 \\
4.8 \pm 0.7 \\
2.1 \pm 1.0 \\
4.4 \pm 0.4 \\
4.96 \pm 0.05 \\
11.4 \pm 0.5 \\
4.28 \pm 0.16\end{array}$ & $\begin{array}{l}0.08 \\
0.02 \\
0.47 \\
0.37 \\
0.44 \\
0.32 \\
0.18\end{array}$ & $\begin{array}{l}0.97 \\
0.99 \\
0.71 \\
0.77 \\
0.72 \\
0.81 \\
0.91\end{array}$ \\
\hline August 2011 & $\begin{array}{l}\text { mineral N }(\mathrm{mg} / \mathrm{kg}) \\
\mathrm{N}-\mathrm{NO}_{3}(\mathrm{mg} / \mathrm{kg}) \\
\mathrm{N}-\mathrm{NH}_{4}(\mathrm{mg} / \mathrm{kg}) \\
\mathrm{P}^{-} \mathrm{PO}_{4}(\mathrm{mg} / \mathrm{kg}) \\
\mathrm{K}(\mathrm{mg} / \mathrm{kg}) \\
\mathrm{pH} \mathrm{KCl} \\
\text { moisture }(\%) \\
\text { organic matter }(\%)\end{array}$ & $\begin{aligned} 5.8 & \pm 1.3 \\
0.5 & \pm 0.2 \\
5.3 & \pm 1.3 \\
4.9 & \pm 0.2 \mathrm{~b} \\
103.7 & \pm 11.0 \mathrm{~b} \\
5.21 & \pm 0.04 \mathrm{~b} \\
15.1 & \pm 0.3 \\
4.8 & \pm 0.1\end{aligned}$ & $\begin{aligned} 8.0 & \pm 1.8 \\
0.6 & \pm 0.2 \\
7.4 & \pm 1.8 \\
4.5 & \pm 0.4 \mathrm{ab} \\
108.9 & \pm 12.4 \mathrm{~b} \\
5.35 & \pm 0.09 \mathrm{~b} \\
15.7 & \pm 0.2 \\
4.9 & \pm 0.1\end{aligned}$ & $\begin{aligned} 9.7 & \pm 2.0 \\
0.9 & \pm 0.2 \\
8.9 & \pm 1.9 \\
4.2 & \pm 0.2 \mathrm{ab} \\
64.9 & \pm 13.0 \mathrm{ab} \\
5.12 & \pm 0.06 \mathrm{ab} \\
15.2 & \pm 0.3 \\
4.6 & \pm 0.1\end{aligned}$ & $\begin{aligned} 3.4 & \pm 1.1 \\
0.2 & \pm 0.1 \\
3.2 & \pm 1.1 \\
3.8 & \pm 0.2 \mathrm{a} \\
46.2 & \pm 9.3 \mathrm{a} \\
4.93 & \pm 0.04 \mathrm{a} \\
14.8 & \pm 0.3 \\
4.5 & \pm 0.1\end{aligned}$ & $\begin{array}{l}1.28 \\
2.82 \\
0.83 \\
5.22 \\
9.40 \\
6.82 \\
0.84 \\
1.78\end{array}$ & $\begin{array}{c}0.32 \\
0.08 \\
0.50 \\
\mathbf{0 . 0 1} \\
<\mathbf{0 . 0 0 1} \\
\mathbf{0 . 0 0 4} \\
0.49 \\
0.19\end{array}$ \\
\hline
\end{tabular}

Note: Within rows, entries followed by the same letter are not significantly different $(P<0.05)$ based on a Tukey's HSD test $(n=6)$. 


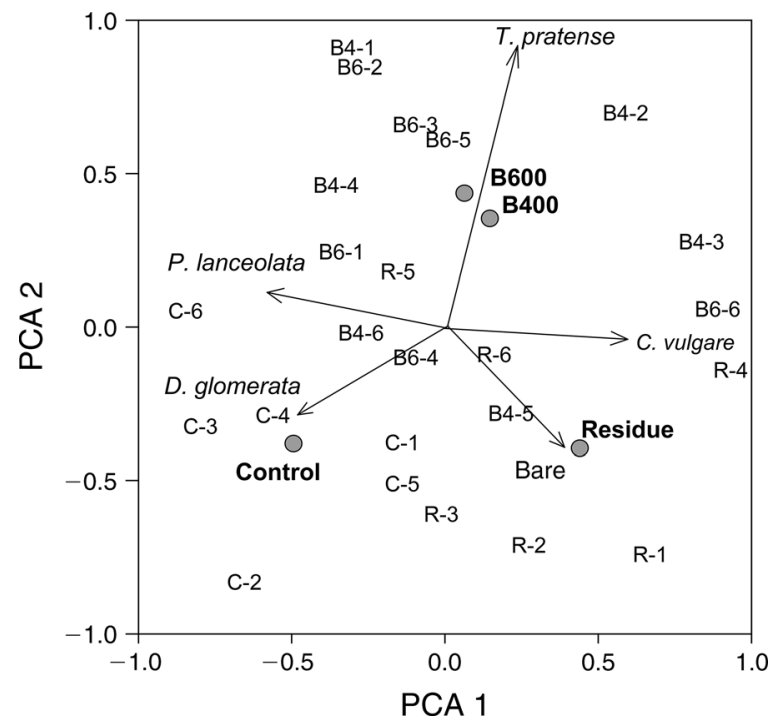

FIG. 1. Principal components analysis (PCA) of sample scores of the 24 field plots (Biochar 400, B4; Biochar 600, B6; control, $\mathrm{C}$; hay residue, $\mathrm{R}$; and the block from which they originated, e.g., B4-1), and the species scores (for plants present in the plant communities) of the four plant species with the highest scores. Species names are: Cirsium vulgare, Dactylis glomerata, Plantago lanceolata, Trifolium pratense. The percentage of bare soil was also included in the analyses. The gray circles indicate the means for the four experimental treatments: Biochar 400 (B400), Biochar 600 (B600), Hay residue (Residue), and Control.

control or biochar plots in the field experiment (Biochar, $F_{1,16}=0.59, P=0.45$; control, $\left.F_{1,16}=1.69, P=0.12\right)$.

\section{Plant nutrients}

Plant $\mathrm{N}$ concentration, measured in $H$. lanatus, $P$. lanceolata, $T$. pratense, and $V$. cracca, was significantly lower in the control than in the hay residue treatment, but did not significantly differ from the biochar treatments (N, $F_{3,75}=3.14, P=0.03$; Fig. 3). Plant K concentration was significantly lower in the Control than in the other treatments $\left(\mathrm{K}, F_{3,75}=12.2, P<0.001\right.$; Fig. 3). Plant $P$ concentration did not differ significantly between treatments $\left(\mathrm{P}, F_{3,75}=1.63, P=0.19\right.$; Fig. 3). Plant $\mathrm{K}$ concentration was, for all species, significantly positively correlated with soil $\mathrm{K}$ content $(H$. lanatus, $P=$ 0.04; $P$. lanceolata, $P<0.01 ; T$. pretense, $P=0.02 ; V$. cracca, $P<0.01$ ), but this was not the case for plant and soil $\mathrm{N}$ and $\mathrm{P}$. Plant N, P, and $\mathrm{K}$ concentration also differed significantly between plant species (all $P<$ 0.001; Fig. 3). There were no significant interactions between treatments and plant species.

The N:K ratio was significantly higher in the control treatment than in both biochar treatments $\left(F_{3,75}=6.19\right.$, $P<0.001)$. The $\mathrm{P}: \mathrm{K}$ ratio was highest in the control treatment $\left(F_{3,75}=10.7, P<0.001\right)$, but the N:P ratio did not significantly differ between treatments $\left(F_{3,75}=1.15\right.$, $P=0.09)$. All ratios differed significantly between plant species (Appendix: Fig. A1).

\section{Biological nitrogen fixation}

The percentage of $\mathrm{N}$ derived from the atmosphere (\%Ndfa) in the legumes $T$. pratense and $V$. cracca did not differ between the two species $\left(F_{1,35}=0.29, P=\right.$ $0.59)$, nor between treatments $\left(F_{3,35}=0.22, P=0.88\right.$; Fig. 4a). However, total $\mathrm{N}$ derived from atmosphere per $T$. pratense plant was significantly higher in both biochar treatments than in the Control treatment $\left(F_{3,20}=7.04, P\right.$ $=0.002$; Fig. $4 \mathrm{~b}$ ), which was not due to enhanced rates of biological fixation, but due to the higher biomass accumulation of these plants.

\section{DisCusSION}

Soil amendment with biochar in a natural grassland resulted immediately in strong effects on plant community composition and soil nutrient status in the first growing season, even though total productivity was not altered. The effects on plant community composition were mainly due to a strong increase in legume abundance and biomass production of individual $T$. pratense plants following biochar amendment. We discuss the mechanisms that may underlie these rapid effects on plant community composition and the beneficial effect on legumes.

\section{Biochar does not alter plant productivity, but does change community composition}

In contrast to the results of a recent meta-analysis (Jeffery et al. 2011), total plant productivity in our experiment was not enhanced by the addition of $10 \mathrm{Mg}$ /

TABLE 3. Percentage cover of the different plant functional groups per treatment in the experimental field site at harvest (August 2011).

\begin{tabular}{lcccrcc}
\hline \hline \multicolumn{1}{c}{ Parameters } & Biochar 400 & Biochar 600 & Hay residue & Control & $F_{3,15}$ & $P$ \\
\hline Total cover (\%) & $136.0 \pm 9.2$ & $133.2 \pm 8.2$ & $115.6 \pm 6.3$ & $115.0 \pm 2.6$ & 2.70 & 0.08 \\
Forbs (\%) & $90.5 \pm 6.0$ & $86.4 \pm 3.6$ & $91.0 \pm 5.1$ & $92.5 \pm 2.9$ & 1.64 & 0.22 \\
Legumes (\%) & $39.3 \pm 8.4 \mathrm{~b}$ & $41.2 \pm 6.5 \mathrm{~b}$ & $20.3 \pm 3.6 \mathrm{ab}$ & $14.4 \pm 2.5 \mathrm{a}$ & 5.27 & $\mathbf{0 . 0 1}$ \\
Grasses (\%) & $6.2 \pm 1.0 \mathrm{ab}$ & $5.6 \pm 0.4 \mathrm{ab}$ & $4.3 \pm 0.5 \mathrm{a}$ & $8.1 \pm 1.1 \mathrm{~b}$ & 3.78 & $\mathbf{0 . 0 4 6}$ \\
Non-sown species (\%) & $26.0 \pm 5.1 \mathrm{ab}$ & $24.2 \pm 5.6 \mathrm{ab}$ & $36.4 \pm 8.4 \mathrm{~b}$ & $15.8 \pm 2.1 \mathrm{a}$ & 3.38 & 0.06 \\
Bare soil (\%) & $3.1 \pm 0.8$ & $3.2 \pm 0.6$ & $5.9 \pm 1.4$ & $2.8 \pm 0.6$ & 2.86 & 0.07 \\
\hline
\end{tabular}

Notes: Means \pm SE and $F$ and $P$ values of ANOVA testing differences between treatments are presented. Within rows, entries followed by the same letter are not significantly different $(P<0.05)$ based on a Tukey's HSD test $(n=6)$. 

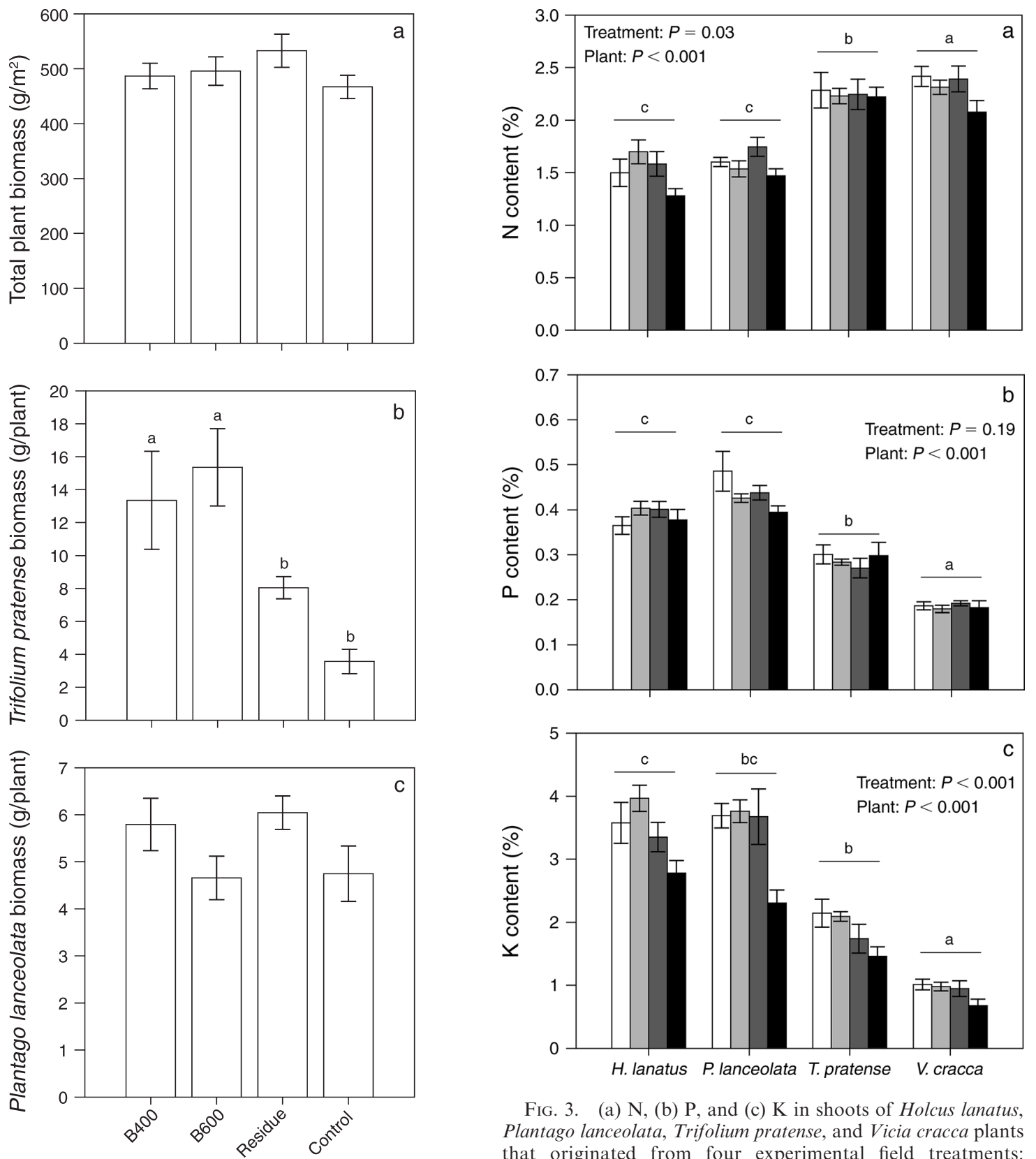

Fig. 3. (a) $\mathrm{N}$, (b) $\mathrm{P}$, and (c) $\mathrm{K}$ in shoots of Holcus lanatus, Plantago lanceolata, Trifolium pratense, and Vicia cracca plants that originated from four experimental field treatments: Biochar 400 (white bars), Biochar 600 (light gray bars), Hay residue (dark gray bars), and Control (black bars); values are mean percentage $( \pm \mathrm{SE})$. Significance of treatment and plant species based on a two-way ANOVA are also presented (mean $\pm \mathrm{SE})$. The treatment $\times$ plant species interaction was never significant. Different lowercase letters indicate significant differences $(P<0.05)$ between species, based on a Tukey's HSD post hoc test.

ha biochar. Although biochar did not affect total aboveground productivity, biochar amendment affected the composition of the plant community. We tested specifically if this was due to biochar amendment affecting germination rates or to the affect on the growth of certain species or functional groups. We found no evidence that biochar amendment changed

germination of any of the tested species. Therefore, it seems more likely that the species-specific plant growth and thus competitive hierarchy was changed, indicating that compensatory dynamics may play a role in biocharamended plots. We analyzed several abiotic factors, such as changes in moisture content, organic matter content, soil $\mathrm{N}$ content, micronutrients, but we found no 

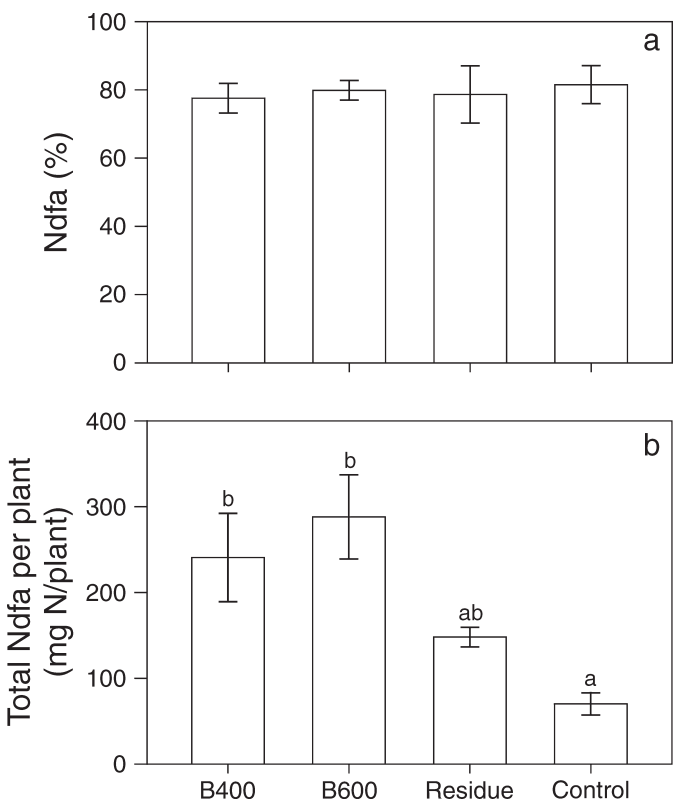

FIG. 4. (a) Percentage nitrogen (N) derived from atmosphere (Ndfa) and (b) total $\mathrm{N}$ derived from atmosphere in Trifolium pratense plants per field treatment; values are mean \pm $\mathrm{SE} ; n=6)$. Different lowercase letters indicate significant differences $(P<0.05)$, based on a Tukey's HSD post hoc test.

significant differences between treatments on these abiotic conditions. However, soil $\mathrm{pH}$, soil $\mathrm{PO}_{4}$, and soil $\mathrm{K}$ were significantly increased in biochar plots. This was likely advantageous to legumes, since these are not limited by $\mathrm{N}$ due to their symbiosis with $\mathrm{N}$-fixing bacteria, and thus may benefit disproportionally from increased $\mathrm{P}$ and $\mathrm{K}$ availability in the soil. However, only plant $\mathrm{K}$ concentration was significantly altered by biochar addition, which would specifically point at the importance of biochar-mediated $\mathrm{K}$ availability. Indirectly, soil $\mathrm{pH}$ and nutrient status can also affect the soil biotic community (e.g., Dumbrell et al. 2010), which in turn could have affected the performance and competitive ability of some plant species. Alternatively, biochar addition in our study may have absorbed plant allelochemicals and consequently have affected some plant species, as has been shown for activated carbon (Kulmatiski and Beard 2006, Callaway et al. 2011).

Plant community composition in the hay residue treatment also differed from the control plots and was characterized by a larger proportion of bare ground and early-successional agricultural weeds (Fig. 1). This result may have been caused by the low bulk density of the hay residue compared to the biochar. As a consequence, a larger volume was incorporated in the top $10 \mathrm{~cm}$ in the Hay residue treatment, resulting in an uplifting of the soil surface. In combination with a drought during the spring in 2011, this could have resulted in reduced water availability and increased mortality of young seedlings. The resulting open spaces may have been colonized by propagules of agricultural weeds.

\section{Biochar enhances legume performance}

In response to soil amendment with biochar, legume abundance and the biomass of individual $T$. pratense plants increased, whereas the biomass of the most abundant forb, P. lanceolata, was not altered. This positive effect of biochar on legumes has been reported before, for example, in a short-term study with common beans (Phaseolus vulgaris L.) by Rondon et al. (2007). They related this effect to an increase in biologically fixed nitrogen, which was also reported to increase in soybean in the presence of biochar by Tagoe et al. (2008) and Ogawa and Okimori (2010). Rondon et al. suggested that the increased rate of biological $\mathrm{N}$ fixation may be due to increased soil $\mathrm{pH}$ or increased availability of some limiting macro- and micronutrients. However, in a long-term field study (three years), total nitrogenase activity of a whole clover root system remained unaffected by biochar amendment (Quilliam et al. 2012). Also in our study, investigations of the percentage of $\mathrm{N}$ derived from the atmosphere in the legumes did not yield any evidence for enhanced rates of BNF in soils with biochar. Even though the rate of BNF did not change, on a per plant basis $T$. pratense plants from biochar-amended plots contained in total four times more $\mathrm{N}$ that originated from the atmosphere than T. pratense plants from the control plots. This was mainly due to the higher biomass accumulation of $T$. pratense plants in biochar-amended plots. This suggests that the ability of legumes to use atmospheric nitrogen also made it possible to utilize the higher availability of $\mathrm{K}$ and $\mathrm{P}$ in biochar plots as compared to the nonlegumes (Mengel and Kirkby 1987). It is known that legumes in particular can benefit from increased soil K availability (Sangakkara et al. 1996). Indeed, K concentration in plant tissue was highest in the biochar treatments. In our study, we found no indications that the increased availability of other (micro-) nutrients stimulated legumes.

\section{Biochar control treatments}

The results of our study highlight the importance of including correct control treatments in biochar research, a point that has gained recent interest (Jeffery et al. 2014). The majority of studies on biochar amendment compare a biochar addition treatment with a control treatment without any soil amendment. However, for many of the observations in this study, for example soil $\mathrm{PO}_{4}, \mathrm{~K}$, and $\mathrm{pH}$, we found significant differences between the Control (no amendment) and biochar treatments, but no difference between biochar and the Hay residue treatments. Conversely, plant $\mathrm{N}$ concentration, for example, was only affected by hay residue incorporation and not by biochar amendment. These observations show that in some cases the addition of any organic substrate can be more important than the fact that it is specifically biochar. 


\section{Long-term cascading effects of biochar}

Within the first growing season we observed strong and significant effects of biochar addition on soil nutrients and plant community composition. Over time these observations are expected to further cascade to other (soil) organisms and ecosystem processes. However, it remains to be seen whether and how these changes will affect ecosystem functioning over time. Future effects could occur via a multitude of mechanisms, such as via alterations in chemical or physical soil conditions. In our example, the increased soil $\mathrm{K}$ content or increased $\mathrm{pH}$ will give a competitive advantage to species that perform better with a higher $\mathrm{K}$ content or $\mathrm{pH}$. Indirectly, the altered soil $\mathrm{pH}$ or nutrient levels can also change the composition of the microbial community (Jones et al. 2012, Quilliam et al. 2013), including arbuscular mycorrhizal fungi (Dumbrell et al. 2010), which can then affect plant performance. On the other hand, the observed alterations in plant community composition will also affect soil community composition, as each plant species creates its own soil biotic community (Bezemer et al. 2010). Via biotic plant-soil interactions, these species-specific soil communities can differentially affect the growth of subsequent plant species growing in that soil, which could then alter the succession of the community as a whole (van de Voorde et al. 2011, Hendriks et al. 2013). Even when the direct effects of biochar addition disappear rapidly in the following growing seasons, for example, due to leaching or utilization of mobile ions such as K, the effect of biochar addition will remain visible in the plant community and in the ecosystem via altered mechanisms like seed production, competition, and plant-soil interactions over a much longer period. Of course, when the direct effects of biochar amendment are present for a longer period, for example, due to the use of pelletized biochar, these direct and indirect effects will occur simultaneously.

\section{Concluding remarks}

This study in a Dutch nature restoration area demonstrates that biochar amendment can have strong and rapid effects on plant community composition and soil nutrient status. Over time, these effects could cascade up to other trophic layers such as above- and belowground organisms, which may have long-term consequences for the functioning and composition of the ecosystem. These results emphasize the need for longterm field studies, with well-designed controls, that study not only the short-term effects of biochar amendment, but also follow how these effects cascade up to other groups over time, affecting the ecosystem as a whole. Potentially, applying biochar to wastelands and (semi-) natural systems could be a way of sequestering carbon (Woolf et al. 2010), which could then potentially become a way to finance the maintenance and production costs of these restoration areas. However, more long-term experiments are needed first.
ACKNOWLEDGMENTS

The authors thank Frans Möller, Jan van Walsem, Gerlinde De Deyn, Jasper van Ruijven, Shamim Mia Xei Fue, Yunlu Fu (all WUR), Florentine van Noppen, Pella Brinkman, Janna Barel, Jarno Sinnige, Henk Martens (all NIOO-KNAW), and Jenn Schweitzer for their practical help, Hannie de Caluwe (RU) for measuring micronutrients, and Natuurmonumenten for giving permission to perform this study on their property. This project was funded by the Emerging Science fund of the Production Ecology and Resource Conservation (PE\&RC) graduate school of Wageningen UR. L. Mommer was supported by a NWO Veni grant. This is publication 5532 of the Netherlands Institute of Ecology (NIOO-KNAW).

\section{Literature Cited}

Angın, D., T. E. Köse, and U. Selengil. 2013. Production and characterization of activated carbon prepared from safflower seed cake biochar and its ability to absorb reactive dyestuff. Applied Surface Science 280:705-710.

Bezemer, T. M., et al. 2010. Divergent composition but similar function of soil food webs of individual plants: plant species and community effects. Ecology 91:3027-3036.

Blumenthal, D. M., N. R. Jordan, and M. P. Ruselle. 2003. Soil carbon addition controls weeds and facilitates prairie restoration. Ecological Applications 13:605-615.

Callaway, R. M. 2000. Invasive plants versus their new and old neighbors: a mechanism for exotic invasion. Science 290:521523 .

Callaway, R. M., E. J. Bedmar, K. O. Reinhart, C. G. Silvan, and J. Klironomos,. 2011. Effects of soil biota from different ranges on Robinia invasion: acquiring mutualists and escaping pathogens. Ecology 92:1027-1035.

Downie, A., L. van Zwieten, W. Doughty, and F. Joseph. 2007. Nutrient retention characteristics of chars and the agronomic implications. Proceedings of the International Agrichar Inititiave (IAI) Conference, Terrigal, New South Wales, Australia.

Dumbrell, A. J., M. Nelson, T. Helgason, C. Dytham, and A. H. Fitter. 2010. Relative roles of niche and neutral processes in structuring a soil microbial community. ISME Journal 4:337-45.

Free, H. F., C. R. McGill, J. S. Rowarth, and M. J. Hedley. 2010. The effect of biochars on maize (Zea mays) germination. New Zealand Journal of Agricultural Research 53:1-4.

Glaser, B., J. Lehmann, and W. Zech. 2002. Ameliorating physical and chemical properties of highly weathered soils in the tropics with charcoal-a review. Biology and Fertility of Soils 35:219-230.

Gundale, M. J., and T. H. DeLuca. 2006. Temperature and source material influence ecological attributes of ponderosa pine and Douglas-fir charcoal. Forest Ecology and Management 231:86-93.

Hendriks, M., L. Mommer, H. de Caluwe, A. E. Smit-Tiekstra, W. H. van der Putten, and H. de Kroon. 2013. Independent variations of plant and soil mixtures reveal soil feedback effects on plant community overyielding. Journal of Ecology 101:287-297.

Houba, V. J. G., I. Novozamsky, A. W. M. Huijbregts, and J. J. van der Lee. 1986. Comparison of soil extractions by $0.01 \mathrm{M}$ $\mathrm{CaCl}_{2}$, by UAF and some conventional extraction procedures. Plant and Soil 96:433-437.

Houba, V. J. G., E. J. M. Temminghoff, G. A. Gaikhorst, and W. van Vark. 2000. Soil analysis procedures using 0.01 M calcium chloride as extraction reagent. Communications in Soil Science and Plant Analysis 31:9-10.

Jeffery, S., T. M. Bezemer, G. Cornelissen, Th. W. Kuyper, J. Lehmann, L. Mommer, S. Sohi, T. F. J. van de Voorde, D. A. Wardle, and J. W. Van Groenigen. 2014. The way forward in soil biochar research: targeting trade-offs between 
the potential wins. Global Change Biology Bioenergy. http:// dx.doi.org/10.1111/gcbb.12132

Jeffery, S., F. G. A. Verheijen, M. van der Velde, and A. C. Bastos. 2011. A quantitative review of the effects of biochar application to soils on crop productivity using meta-analysis. Agriculture, Ecosystems and Environment 144:175-187.

Jones, D. L., J. Rousk, G. Edwards-Jones, T. H. DeLuca, and D. V. Murphy. 2012. Biochar-mediated changes in soil quality and plant growth in a three year field trial. Soil Biology and Biochemistry 45:113-124.

Kammann, C. I., S. Linsel, J. W. Gößling, and H.-W. Koyro. 2011. Influence of biochar on drought tolerance of Chenopodium quinoa Willd and on soil-plant relations. Plant and Soil 345:195-210.

Kardol, P., T. M. Bezemer, and W. H. van der Putten. 2009. Soil organism and plant introductions in restoration of species-rich grassland communities. Restoration Ecology 17:258-269.

Kulhánek, M., J. Balík, J. Černý, and V. Vaněk. 2009. Evaluation of phosphorus mobility in soil using different extraction methods. Plant Soil and Environment 55:267-272.

Kulmatiski, A. 2011. Changing soils to manage plant communities: activated carbon as a restoration tool in ex-arable fields. Restoration Ecology 19:102-110.

Kulmatiski, A., and K. Beard. 2011. Long-term plant growth legacies overwhelm short-term plant growth effects on soil microbial community structure. Soil Biology and Biochemistry $43: 823-830$.

Lehmann, J., J. P. da Silva, and C. Steiner. 2003. Nutrient availability and leaching in an archaeological Anthrosol and a Ferralsol of the Central Amazon basin: fertilizer, manure and charcoal amendments. Plant and Soil 249:343-357.

Lehmann, J., J. Gaunt, and M. Rondon. 2006. Bio-char sequestration in terrestrial ecosystems - a review. Mitigation and Adaptation Strategies for Global Change 11:395-419.

Lehmann, J., and S. Joseph. 2009. Biochar for environmental management science and technology. Earthscan, London, UK.

Lepš, J., P. Šmilauer, and P. Smilauer. 2003. Multivariate analysis of ecological data using CANOCO. Cambridge University Press, Cambridge, UK.

Liu, Y., M. Yang, Y. Wu, H. Wang, Y. Chen, and W. Wu. 2011. Reducing $\mathrm{CH}_{4}$ and $\mathrm{CO}_{2}$ emissions from waterlogged paddy soil with biochar. Journal of Soils and Sediments 11:930-939.

Major, J., C. Steiner, A. Ditommaso, N. P. S. Falcão, and J. Lehmann. 2005. Weed composition and cover after three years of soil fertility management in the central Brazilian Amazon: compost, fertilizer, manure and charcoal applications. Weed Biology and Management 5:69-76.

Mengel, K., and E. A. Kirkby. 1987. Principles of plant nutrition. Fourth edition. International Potash Institute, Horgen, Switzerland.

Mikan, C., and M. Abrams. 1996. Mechanisms inhibiting the forest development of historic charcoal hearths in southeastern Pennsylvania. Canadian Journal of Forest Research 26:1893-1898.

Novozamsky, I., V. J. G. Houba, D. van der Eijk, and R. van Eck. 1983. Notes on determinations of nitrate in plant material. Netherlands Journal of Agricultural Science 31:239-248.

Ogawa, M., and Y. Okimori. 2010. Pioneering works in biochar research, Japan. Australian Journal of Soil Research 2 48:489-500.

Payne, R. W., et al. 2008. The guide to GenStat Release 11, Part 2: statistics. VSN International, Hemel Hempstead, UK.

Perry, L. G., D. M. Blumenthal, T. A. Monaco, M. W. Paschke, and E. F. Redente. 2010. Immobilizing nitrogen to control plant invasion. Oecologia 163:13-24.
Quilliam, R. S., T. H. DeLuca, and D. L. Jones. 2013. Biochar application reduces nodulation but increases nitrogenase activity in clover. Plant and Soil 366:83-92.

Quilliam, R. S., K. A. Marsden, C. Gertler, J. Rousk, T. H. DeLuca, and D. L. Jones. 2012. Nutrient dynamics, microbial growth and weed emergence in biochar amended soil are influenced by time since application and reapplication rate. Agriculture, Ecosystems and Environment 158:192-199.

Rondon, M. A., J. Lehmann, J. Ramírez, and M. Hurtado. 2007. Biological nitrogen fixation by common beans (Phaseolus vulgaris L.) increases with bio-char additions. Biology and Fertility of Soils 43:699-708.

Sangakkara, U., U. Hartwig, and J. Nösberger. 1996. Soil moisture and potassium affect the performance of symbiotic nitrogen fixation in faba bean and common bean. Plant and Soil 184:123-130.

Shearer, G., and D. H. Kohl. 1986. $\mathrm{N}_{2}$ fixation in field settings: estimates based on natural ${ }^{15} \mathrm{~N}$ abundance. Australian Journal of Plant Physiology 13:699-756.

Singh, B. P., B. J. Hatton, B. Singh, A. L. Cowie, and A. Kathuria. 2010. Influence of biochars on nitrous oxide emission and nitrogen leaching from two contrasting soils. Journal of Environment Quality 39:1224.

Sohi, S., E. Krull, E. Lopez-Capel, and R. Bol. 2010. A review of biochar and its use and function in soil. Advances in Agronomy 105:47-82.

Solaiman, Z. M., D. V. Murphy, and L. K. Abbott. 2011. Biochars influence seed germination and early growth of seedlings. Plant and Soil 353:273-287.

Sombroek, W. G. 1966. Amazon soils: a reconnaissance of the soils of the Brazilian Amazon region. Verslag Landbouwkundig Onderzoek 283. Centrum voor Landbouwpublikaties en Landbouwdocumentatie, Wageningen, The Netherlands.

Spokas, K. A. 2010. Review of the stability of biochar in soils: predictability of O:C molar ratios. Carbon Management 1:289-303.

Spokas, K. A., et al. 2012. Biochar: a synthesis of its agronomic impact beyond carbon sequestration. Journal of Environmental Quality 41:973-989.

Stiboka. 1975. Bodemkaart van Nederland. Stiboka, Wageningen, The Netherlands.

Tagoe, S. O., T. Horiuchi, and T. Matsui. 2008. Effects of carbonized and dried chicken manures on the growth, yield, and $\mathrm{N}$ content of soybean. Plant and Soil 306:211-220.

Ter Braak, C. J. F., and P. Šmilauer. 2002. CANOCO reference manual and CanoDraw for Windows user's guide: software for canonical community ordination (version 4.5). Microcomputer Power, Ithaca, New York, USA.

Vaccari, F. P., S. Baronti, E. Lugato, L. Genesio, S. Castaldi, F. Fornasier, and F. Miglietta. 2011. Biochar as a strategy to sequester carbon and increase yield in durum wheat. European Journal of Agronomy 34:231-238.

Van de Voorde, T. F. J., W. H. van der Putten, and T. M. Bezemer. 2011. Intra- and interspecific plant-soil interactions, soil legacies and priority effects during old-field succession. Journal of Ecology 99:945-953.

Van Zwieten, L., S. Kimber, S. Morris, K. Y. Chan, A. Downie, J. Rust, S. Joseph, and A. Cowie. 2010. Effects of biochar from slow pyrolysis of papermill waste on agronomic performance and soil fertility. Plant and Soil 327:235-246.

Wang, J., X. Pan, Y. Liu, X. Zhang, and Z. Xiong. 2012. Effects of biochar amendment in two soils on greenhouse gas emissions and crop production. Plant and Soil 360:287-298.

Woolf, D., J. E. Amonette, F. A. Street-Perrott, J. Lehmann, and S. Joseph. 2010. Sustainable biochar to mitigate global climate change. Nature Communications 1:56.

Zimmerman, A. R. 2010. Abiotic and microbial oxidation of laboratory-produced black carbon (biochar). Environmental Science and Technology 44:1295-301. 
Supplemental Material

Appendix

Mean cover per plant species in field experiment, biochar effect on germination, and mean plant N:P, N:K, and P:K ratios (Ecological Archives A024-067-A1). 